\title{
Pendekatan Historis Kristis Terhadap Bilangan 3 dan 4 tentang Tanggung Jawab Pendeta
}

\author{
Astin Mangean \\ Sekolah Tinggi Agama Kristen Negeri Toraja, Tana Toraja, Sulawesi Selatan \\ astinmangean@gmail.com
}

\begin{abstract}
The tribe of Levi was chosen and ordained by God for hold worsip in tabernacle of the congregation. Their work is simple but they must to do accordingly with their role in Number 3 and 4 and exactly that God command. To investigate and riview the Number 3 and 4, the author uses critical history method by putting attention to the situation in the text and the situatioan gave the text. The role of the tribe of Levi is offer sacrifices and pray, interpretation the urim dan tumim, difference between holy and unholy and between clean and unclean, unload, transport and rebuild the tabernacle. When the tribe of Levi doing the role they must maintain holiness in front of God. Based on that role then the life of tribe of Levi can be a reference for life of priest it mainly concerns the role of serving the Lord.
\end{abstract}

Keywords: discipline; holiness; Number 3 and 4; tribe of Levi

\begin{abstract}
Abstrak: Suku Lewi dipilih dan ditetapkan oleh Tuhan untuk menyelenggarakan ibadat di kemah suci. Mereka harus melaksanakannya sesuai perintah Tuhan. Kajian terhadap peran suku Lewi dalam Bilangan 3 dan 4 menggunakan metode penelitian kepustakaan (Library research) dengan pendekatan kritik historis. Metode ini menaruh perhatian pada situasi yang digambarkan dalam teks dan situasi yang melahirkan teks. Adapun peran suku Lewi yakni mempersembahkan korban-korban serta menaikan doa, menafsirkan urim dan tumim, harus dapat membedakan kudus dan tidak kudus, najis dan tidak najis, memberikan berkat dalam nama Allah, penasihat umat, menjaga kemah suci, membongkar, mengangkut dan mendirikan kembali kemah suci. Ketika melaksanakan peran tersebut suku Lewi harus tetap menjaga kekudusan hidupnya dihadapan Tuhan. Berdasarkan peran tersebut, maka kehidupan suku Lewi dapat menjadi acuan bagi kehidupan pendeta masa kini terutama menyangkut peran sebagai pelayan Tuhan.
\end{abstract}

Kata Kunci: Bilangan 3 dan 4; kedisiplinan; kekudusan; suku Lewi

$\begin{array}{llll}\text { Article History : } & \text { Received: 26-10-2019 } & \text { Revised: 07-12-2019 } & \text { Accepted: 16-12-2019 }\end{array}$

\section{Pendahuluan}

Seorang pendeta berperan penting bagi pertumbuhan dan perkembangan iman jemaat. Peran tersebut mulai dilaksanakan sejak dalam tradisi keimaman bangsa Israel dan mengalami perkembangan sesuai perkembangan tahap kepercayaan dan konteks yang memengaruhi pelayanan. Apabila berbicara tentang tradisi keimaman, maka peran tersebut sebagian besar dilaksanakan oleh suku Lewi. Salah satu dari antara 12 suku 
bangsa Israel, yang dipercaya dan diakui telah dipilih oleh Allah untuk memimpin ritusritus peribadahan.

Sebelum suku Lewi dipilih dan ditetapkan Allah untuk menyelenggarakan ibadat di kemah suci, ibadat pada zaman bapa leluhur disebut sebagai ibadat perseorangan. Ketika mereka mempersembahkan kurban, kurban dipersembahkan di atas sebuah mezbah yang didirikan oleh bapa leluhur itu sendiri dan tidak ada menyinggung tentang peranan seorang imam. ${ }^{1}$ Dalam hal ini bapa leluhur bertindak sebagai imam untuk mempersembahkan kurban kepada Allah.

Suku Lewi terbagi atas tiga keturunan : keturunan Gerson, Kehat dan Merari. Waktu perjalanan di padang gurun masing-masing mereka mempunyai kewajiban tertentu dalam pengusungan kemah suci dan alat-alatnya. Mereka harus melakukan kewajiban dari umur 25 tahun sampai 50 tahun (Bil. 8 : 24, 25). Berdasarkan Bil. 4 : 47 dikatakan antara umur 30 sampai 50 tahun; 5 tahun yang pertama digunakan sebagai latihan dan persiapan sebelum akhirnya melaksanakan perannya secara penuh. ${ }^{2}$ Suku Lewi dikhususkan untuk menjadi pelayan altar, tidak memiliki warisan tanah, tetapi mereka diberi hak dan hidup dari perpuluhan yang diwajibkan dari setiap umat yakni 11 suku yang ada.

Peran keturunan Lewi merupakan peran khusus di tengah bangsa Israel. Bilangan 8:19 "dan Aku menyerahkan orang Lewi dari tengah-tengah orang Israel sebagai pemberian kepada Harun dan anak-anaknya untuk melakukan segala pekerjaan jabatan bagi orang Israel di kemah pertemuan dan untuk mengadakan perdamaian bagi orang Israel, supaya orang Israel jangan kena tulah apabila mereka mendekat ketempat kudus" (TB). Peran imam yang demikian sangat penting di tengah-tengah bangsa Israel, karena pusat kehidupan bangsa Israel adalah pada Allah. Keberadaan imam sendiri dibutuhkan setiap orang berdosa untuk mempersembahkan korban penebusan dosa dan Allah memilih dan menetapkan suku Lewi, keluarga Harun untuk menjadi imam bagi segenap bangsa. ${ }^{3}$ Imam mewakili umat dihadapan Allah dalam mempersembahkan korban. Peran suku Lewi di kemah suci diuraikan secara rinci dalam Bilangan 3 dan 4 baik keluarga Harun yang ditetapkan sebagai imam maupun orang Lewi yang ditetapkan sebagai pembantu imam. Tugas-tugas tersebut berhubungan dengan peralatan kemah suci, di antaranya memelihara segala perabotan kemah suci, mengurus tepung yang terbaik dan minyak serta mengawasi perbendaharaan barang-barang kudus.

Peran suku Lewi dan pendeta masa kini merupakan dua konteks yang berbeda, serta perannya pun berbeda namun peran suku Lewi dalam Perjanjian Lama juga merupakan sebuah peran khusus untuk melayani Tuhan dalam hal peribadatan. Pendeta dalam konteks sekarang perlu melihat kembali peran suku Lewi di tengahtengah bangsa Israel, dimana kehidupan mereka dalam hal peribadatan begitu

${ }^{1}$ H.H. Rowley, Ibadat Israel Kuno, Terj. I.J. Cairns (Jakarta: PT BPK Gunung Mulia, 2014), 16.

2 Philip J. Budd, World Biblical Commentary: Number (Texas: Waco, 1984), 46.

3 Peter Wongsa, Latihan Bagi Umat Allah: Pendidikan Teologi Dalam Kitab Bilangan (Malang: Seminari Alkitab Asia Tenggara, 1988), 54. 
terstruktur dan teroganisir dengan baik. Robert M. Paterson mengatakan bahwa seorang Pendeta sama seperti imam-imam di Israel dahulu, ditetapkan sebagai pemimpin rohani dalam masyarakat atau sekurang-kurangnya di antara anggota jemaat. Pendeta harus mempunyai kuasa untuk membuat tugas kepemimpinan itu serta melayani gereja dengan rajin dan rendah hati. Namun tidak dapat dipungkiri bahwa ada pendeta yang melupakan keperluan jemaatnya atau memberikan teladan yang tidak baik kepada mereka, ${ }^{4}$ bahkan tidak melaksanakan tugas dan tanggungjawabnya sebagaimana mestinya. Seorang pendeta tidak hanya memiliki tanggungjawab untuk mengajarkan firman Tuhan dalam bentuk khotbah kepada umat, tetapi salah satu tanggungjawab seorang pendeta adalah bertanggungjawab atas perabotan yang ada dalam gereja. Tanggungjawab tersebut merupakan tugas yang sederhana namun memiliki dampak bagi umat.

Pendeta dalam jemaat memiliki peran yang sama dengan suku Lewi yakni melayani Tuhan, sehingga untuk melaksanakan peran tersebut seorang pendeta harus memiliki kehidupan emosional yang baik. Salah satunya dalam hal pengambilan keputusan. Melihat realita sekarang, banyak pendeta yang tidak sehat secara emosi selalu memiliki kegiatan berlebihan. Meskipun mereka terus menerus kekurangan waktu untuk melakukan banyak kegiatan, namun mereka terus mengiyakan semua kesempatan baru sebelum mendoakan dan memikirkannya dengan seksama apakah ini memang kehendak Allah. ${ }^{5}$ Pendeta harus memiliki kehidupan emosional yang baik, sehingga pelayanan dalam jemaat bisa dilakukan dengan baik. Kajian ini bermaksud memaparkan peran suku Lewi secara khusus dalam Bilangan 3 dan 4 kemudian merefleksikannya dalam hubungan dengan tanggung jawab pendeta sebagai pelayan Tuhan.

\section{Metode Penelitian}

Adapun metode yang digunakan dalam penelitian ini adalah metode kualitatif yaitu metode penelitian kepustakaan (Library research), menggunakan kritik historis, dengan menaruh perhatian pada situasi yang digambarkan dalam teks dan situasi yang melahirkan teks itu. Dengan metode kritik historis kondisi-kondisi kebudayaan dan kesejarahan yang melahirkan semua tulisan alkitabiah perlu diperhatikan untuk mengerti teks. ${ }^{6}$ Metode historis ialah metode yang meninjau kembali letak historis dan geografis kitab dan berupaya menunjukan pengaruhnya terhadap penafsiran. ${ }^{7}$ Penelitian kepustakaan ini dilakukan terhadap berbagai sumber data antara lain : Alkitab, tafsirantafsiran dan buku-buku yang membahas "suku Lewi".

\footnotetext{
${ }^{4}$ Robert M. Paterson, Kitab Imamat (Jakarta: BPK Gunung Mulia, 2015), 129-130.

5 Peter Scazzero, The Emotional Healthy Leader (Surabaya : Literatur Perkantas Jawa Timur, 2015), 29.

${ }^{6}$ John H. Hayes dan Carl R. Holladay, Pedoman Penafsiran Alkitab (Jakarta: BPK Gunung Mulia, 2013), 53.

${ }^{7}$ Andreas B. Subagyo, Pengantar Riset Kuantitatif dan Kualitatif: Termasuk Riset Teologi dan Keagamaan (Bandung: Yayasan Kalam Hidup, 2014), 142.
} 


\section{Hasil dan Pembahasan}

\section{Kultus Peribadatan Dalam Perjanjian Lama}

Berbicara tentang kultus peribadatan dalam Perjanjian Lama tidak dapat dipisahkan dari kehidupan bangsa Israel pada saat itu, mulai dari zaman bapa leluhur sampai bangsa Israel memasuki tanah perjanjian yakni Kanaan. Kultus dihubungkan dengan konsepsi persekutuan perjanjian antara Allah dengan bangsa Israel. ${ }^{8}$ Dalam hal ini kultus ialah untuk memelihara relasi antara Yahweh dengan umat-Nya. Perayaanperayaan yang dilakukan oleh bangsa Israel bermaksud memelihara relasi ini. Di dalam kultus, Allah dipuji dan dosa "diperdamaikan/dihapuskan/ diampuni". Pendamaian ini adalah pekerjaan Allah, dilaksanakan oleh imam-imam atas nama Allah dan menggunakan "darah" binatang kurban.

Pada zaman bapa leluhur kultus peribadatan mereka disebut sebagai ibadat perseorangan. Ketika mereka mempersembahkan kurban, kurban dipersembahkan di atas sebuah mezbah yang didirikan oleh bapa leluhur itu sendiri. ${ }^{9}$ Ketika Tuhan menampakkan diri kepada Abraham dan berjanji akan memberikan negeri kepadanya, maka Abraham mendirikan sebuah mezbah bagi Tuhan (Kej. 12:7). Yakub juga mempersembahkan korban sembelihan kepada Tuhan (Kej. 31 : 54). Pada zaman bapa leluhur belum ada peran imam dan juga tempat yang khusus untuk melaksanakan peribadatan kepada Tuhan. Bapa leluhur menyembah Allah yang memperlihatkan diriNya, yang telah memilih dan berjanji menyertai mereka.

Persembahan yang dipersembahkan bapa leluhur merupakan pernyataan rasa khidmat mereka pribadi terhadap ilahi; juga merupakan pengekspresian ibadat mereka pribadi; bukan partisipasi mereka dalam suatu kultus yang sudah resmi serta umum. Rasa syukur mereka, bilamana mereka merasa dikunjungi secara pribadi oleh Allah, entah dalam bentuk perkunjungan oknum ilahi, entah dalam bentuk malaikat atau dalam mimpi, diekspresikan mereka dengan mempersembahkan kurban. Juga bilamana mereka ingin memanggil nama Tuhan serta menghadap kepada Tuhan dalam ibadat, bentuk dan jenis kurban yang dipakainya, hampir tidak disinggung. Perhatian dipusatkan kepada respon yang ingin mereka tunjukan kepada Allah yang mendekati mereka atau dipusatkan kepada kerinduan mereka untuk mendekati Allah dalam memanggil nama-Nya. Kurban yang mereka persembahkan tidak merupakan suatu sistem ibadat begitu saja, melainkan betul-betul suatu pernyataan isi hati mereka, suatu pernyataan rasa khidmat mereka di hadapan Allah. Abraham mempersembahankan kurban dihadapan Tuhan. Kurban tersebut adalah anaknya sendiri yang merupakan bentuk pengabdian kepada Allah.

Setelah orang Israel berkembang menjadi masyarakat yang terstruktur, muncullah kelompok orang yang bertindak secara khusus melayani kebutuhan religius mereka. Selama 40 tahun pengembaraan di padang gurun, mereka memimpin ibadah di kemah

\footnotetext{
8 J.Blommendaal, Pengantar Kepada Perjanjian Lama (Jakarta: BPK Gunung Mulia, 2008), 53.

${ }_{9}^{9}$ H.H. Rowley, Ibadat Israel Kuno, 16.
} 
suci. ${ }^{10}$ Ibadat perseorangan telah berganti menjadi ibadat kelompok yang ditandai dengan berbagai perayaan dan upacara yang harus dilaksanakan oleh bangsa Israel. Perayaan tersebut yakni hari raya roti tidak beragi (Kel. 12 : $14-20$ ), hari raya tujuh Minggu (Kel. 23 : 16), hari raya pondok daun (Im. $23: 33$ - 44), hari raya perdamaian (Im. $16: 1$ - 34) dan hari sabat (Im. $23: 3$ ).

\section{Keimamatan Suku Lewi Berdasarkan Sumber P}

Sumber $\mathrm{P}$ atau cerita Imamat merupakan salah satu dari empat sumber cerita di dalam Pentateukh. Sumber P sangat banyak membahas mengenai kultus peribadatan dalam Perjanjian Lama, secara khusus mengenai suku Lewi. Sumber yang lain yaitu; sumber yang menggunakan nama "Yahwe" (Y), sumber yang menggunakan nama "Elohim" (E) dan sumber yang khususnya terdapat dalam kitab Ulangan atau Deuteronomium (D). ${ }^{11}$ Sumber P berasal dari para imam, mereka mengumpulkan, menghimpun, menulis dan mendokumentasikan bahan-bahan tersebut antara tahun 550-500 sM, yakni pada masa pembuangan di Babel. ${ }^{12}$ Sebelum terjadinya pembuangan, para imam masih bisa melihat bait Allah yang dibangun oleh Salomo (kira-kira 970-930 sM); bait Allah itulah yang menjadi pusat kehidupan nasional dan spiritual mereka selama ini. Namun bait Allah itu dibakar hingga rata dengan tanah oleh raja Nebukadnezar (586 sM). ${ }^{13}$ Peristiwa pembuangan dan terbakarnya bait Allah tentunya membawa dampak bagi kehidupan para imam saat itu.

Para imam yang menyaksikan peristiwa tersebut mencoba melihat kembali ke belakang ke masa silam dan menemukan sebuah alasan untuk tetap berharap. ${ }^{14}$ Ketika berada dipembuangan mereka diberikan izin untuk mengurus rumah tangga mereka sendiri. Kesempatan tersebut digunakan untuk menghimpun, menulis dan mendokumentasikan bahan-bahan tersebut. Kata priest berasal dari bahasa Inggris yang berarti "imam" sehingga kalangan penulis priest atau sering disebut dengan inisial $\mathrm{P}$, terdiri dari para imam Israel. Para penulis $\mathrm{P}$ sangat mementingkan bahan-bahan mengenai kehidupan peribadahan (kultus), karena bagi mereka kultus adalah sarana penting guna memelihara persekutuan antara umat Allah dengan Allah. ${ }^{15}$ Dalam kitab Bilangan banyak berbicara mengenai persekutuan antara umat dengan Allah. Sehingga kitab Bilangan merupakan kumpulan dokumen yang dikumpulkan oleh imam Israel ketika mereka berada di pembuangan. Tradisi imam sendiri selesai dikerjakan pada abad 5 sM. ${ }^{16}$ Dengan selesainya tradisi imam, maka diharapkan kaum buangan yang telah

\footnotetext{
10 Lembaga Biblika Indonesia, Pengantar ke Dalam Taurat (Yogyakarta: Kanisius, 2017), 134.

11 J. Bloomendal, Pengantar Kepada Perjanjian Lama (Jakarta: PT BPK Gunung Mulia, 2008),17.

12 Marthinus Theodorus Mawene, Perjanjian Lama dan Teologi Kontekstual (Jakarta: PT BPK Gunung Mulia, 2012), 171.

13 Karen Armstrong, Sejarah Alkitab; Telaah Historis atas Kitab yang Paling Banyak Dibaca di Seluruh Dunia (Bandung: Mizan, 2014), 29.

14 Ibid, 47.

15 Marthinus Theodorus Mawene, Perjanjian Lama dan Teologi Kontekstual, 171-172.

16 Jarot Hadianto, Misteri Ular Tembaga: Mengenal Kitab Taurat dan Merenungkannya (Jakarta: Lembaga Biblika Indonesia, 2017), 20.
} 
kehilangan semangat akibat terbakarnya bait Allah, tetap memiliki pengharapan kepada Allah dengan membaca bahan-bahan yang telah ditulis kembali oleh para imam.

Berdasarkan sumber D, catatan tentang isi berkat Musa kepada suku Lewi menempati bagian halaman yang lebih banyak dari suku-suku lain (Ul. 33:8-11). Khususnya Ulangan 33:9 menyatakan "yang berkata tentang ayahnya dan tentang ibunya: aku tidak mengindahkan mereka; ia yang tidak mau kenal saudara-saudaranya dan acuh tak acuh terhadap anak-anaknya. Sebab orang-orang Lewi itu berpegang pada firman-Mu dan menjaga perjanjian-Mu". Ayat ini menunjuk pada catatan ketika umat Israel menghadapi krisis kehancuran akibat penyembahan berhala, sementara Musa berada di atas gunung. Suku Lewi saja yang berpihak pada Allah dan memimpin untuk membunuh orang-orang yang melanggar kehendak Allah meskipun orang-orang tersebut adalah orang tua, saudara, teman atau tetangga mereka (Kel. 32). Melalui peristiwa ini, suku Lewi dibebaskan dari seluruh celaka yang dijatuhkan Yakub pada mereka, sebaliknya mereka menerima berkat dari Musa. Pada kenyataannya, suku Lewi menerima berkat terbesar yaitu Tuhan menjadi pusaka abadi mereka. ${ }^{17}$ Oleh karena Tuhan menjadi pusaka mereka, maka seluruh kehidupan dari suku Lewi ialah melayani Tuhan.

\section{Peran Suku Lewi Berdasarkan Bilangan 3 Dan 4}

Peran suku Lewi banyak terdapat dalam Bilangan 3 dan 4. Suku Lewi harus melaksanakan tugasnya di kemah suci atau kemah pertemuan. Kemah suci merupakan tempat bangsa Israel beribadat dan mengadakan pendamaian atas pelanggaranpelanggaran mereka terhadap ketentuan perjanjian Allah. Kemah suci dengan lambanglambang yang ada, merupakan cara Allah yang kudus dan kekal hadir ditengah-tengah umat-Nya atau berkemah diantara mereka. Tabut perjanjian yang merupakan lambang kehadiran Allah di tengah-tengah bangsa Israel berada di dalam kemah suci. Tabut tersebut dibuat dengan sangat sempurna, dengan berbagai aturan dan ukuran yang ada. Hal ini memberikan gambaran bahwa kehadiran Tuhan di tengah bangsa Israel merupakan sesuatu yang sudah direncanakan oleh Tuhan sendiri walaupun kehadiranNya tidak bisa dilihat oleh semua orang. Tabut perjanjian yang berada di ruang mahakudus merupakan tempat menaruh loh hukum yang akan diberikan YHWH kepada bangsa Israel.

Suku Lewi dipilih dan ditetapkan oleh Tuhan untuk melaksanakan peribadatan di kemah suci. Mereka harus melaksanakan tugas tersebut tepat seperti yang diperintahkan oleh Tuhan. Berdasarkan tugasnya maka suku Lewi dibedakan menjadi tiga yakni imam besar, imam dan orang Lewi. Imam besar merupakan jurubicara umat Israel kepada Allah dan jurubicara Allah kepada umat-Nya. Di dalam kemah suci hanya imam besar yang bisa masuk ketempat mahakudus pada hari raya pendamaian. ${ }^{18}$ Hari

\footnotetext{
${ }^{17}$ Abraham Park, Pertemuan yang Terlupakan (Jakarta: Grasindo Yayasan Damai Sejahtera Utama, 2011), 351-352.

18 I. Snoek, Sejarah Suci (Jakarta: PT BPK Gunung Mulia, 2015), 78.
} 
raya tersebut hanya dilaksakan sekali setahun untuk mengadakan pendamaian bagi dosa imam dan umat (Im. 16:1-34).

Kitab Bilangan memberikan uraian perbedaan imam-imam yang berasal dari keturunan Harun dan Lewi yang bukan keturunan Harun. ${ }^{19}$ I Snoek membedakan antara imam dan orang Lewi. Seorang "Imam" berasal dari keturunan Harun dan diluar keturunan Harun adalah orang Lewi yang pekerjaannya adalah pembantu atau melakukan pekerjaan jabatan membantu Harun. ${ }^{20}$ Pekerjaan orang Lewi sebagai pembantu imam tetaplah pekerjaan yang berhubungan dengan peribadatan kepada Allah yang dilaksanakan di tengah-tengah bangsa Israel dan tetap harus harus dilaksanakan tepat seperti yang diperintahkan oleh Tuhan.

Jabatan imam sangat penting bagi kehidupan bangsa Israel, mereka berhubungan langsung dengan perobatan di kemah suci. Imam adalah orang yang ahli dalam hal ibadah, sehingga mereka harus memberikan petunjuk, bimbingan dan keputusan mengenai keagamaan, khususnya aturan ibadah atau aturan korban serta membritakan firman Allah. Sebagai imam yang telah dipilih dan ditetapkan oleh Allah maka terdapat syarat-syarat yang harus mereka penuhi. Salah satu syarat yang harus dipenuhi yakni seorang imam harus menjaga kekudusan hidupnya untuk melakukan pekerjaan bagi Allah yang kudus. Adapun tugas mereka adalah:

\section{Mempersembahkan korban-korban}

Pada hari raya pendamaian imam besar mengadakan pendamaian karena dosa para imam dan segenap bangsa Israel. Sebelum masuk ke dalam ruang mahakudus, imam besar Harun menanggalkan jubah imamatnya, memakai jubah putih dan melaksanakan upacara. Pertama-tama ia mengadakan pendamaian bagi dirinya sendiri dan keluarganya karena ia juga seorang yang berdosa yang dosa-dosanya perlu ditutupi. Lalu ia mempersembahkan seekor domba jantan sebagai kurban penghapus dosa bagi umat Israel. Harun mengambil darah dan memercikannya pada tutup pendamaian di ruang mahakudus. Karena kenajisan umat itu, ruang mahakudus dianggap tercemar dan karenanya memerlukan pendamaian. ${ }^{21}$ Dengan hari raya pendamaian maka seluruh anggota umat Allah dibersihkan dari segala kenajisan dan dosa sehingga menjadi kudus kembali di hadapan Allah.

Imam sebagai pengantara kurban-kurban tersebut sangatlah penting. Imam juga adalah seorang hamba dan harus mengikuti protokol atau tatacara menghadap yang pantas dalam pelayanannya mewakili umat. Sebagai seorang hamba yang khusus, imam harus ditetapkan dan dikuduskan, diajar cara perantaraan yang benar untuk membawa kurban, karena imam adalah orang kudus yang melayani Allah yang kudus untuk 153.

${ }^{19}$ Lembaga Biblika Indonesia, Tafsiran Alkitab Perjanjian Lama (Yogyakarta: PT Kanisius, 2002),

${ }^{20}$ I. Snoek, Sejarah Suci, (Jakarta : PT BPK Gunung Mulia, 2015), 79.

${ }^{21}$ W.S. LaSor dkk, Pengantar Perjanjian Lama 1: Taurat dan Sejarah (Jakarta: PT BPK Gunung Mulia, 2015), 222. 
kepentingan umat yang kudus. ${ }^{22}$ Sebagai pelayan dalam mempersembahkan kurban, imam dituntun untuk hidup dalam kekudusan dan mereka harus tetap belajar bagaimana mempersembahkan kurban kepada Tuhan.

\section{Di Tempat Suci Imam Menafsirkan Urim dan Tumim}

Sifat urim dan tumim tidak diketahui secara pasti, demikian pula makna sesungguhnya dari kedua benda tersebut, sekalipun ada petunjuk bahwa keduanya mungkin merupakan sarana masa itu untuk menentukan apa yang dikehendaki oleh Tuhan. ${ }^{23}$ Urim dan Tumim sebagai sarana menentukan kehendak Tuhan juga terdapat dalam 1 Samuel 14 : 41 ketika raja Saul meminta petunjuk kepada Tuhan. "Lalu berkatalah Saul: "Ya, TUHAN, Allah Israel, mengapa Engkau tidak menjawab hamba-Mu pada hari ini? Jika kesalahan itu ada padaku atau pada anakku Yonatan, ya TUHAN, Allah Israel, tunjukkanlah kiranya Urim; tetapi jika kesalahan itu ada pada umat-Mu Israel, tunjukkanlah Tumim." Lalu didapati Yonatan dan Saul, tetapi rakyat itu terluput" (TB).

Urim dan tumim merupakan wahyu Allah yang disampaikan kepada imam dengan penuh rahasia. Hal tersebut dilakukan dengan cara membuang undi, sedangkan jawabannya yang mungkin ialah "ya" atau "tidak", kadang-kadang urim dan tumim itu dapat memberikan jawaban yang netral. Ketika raja Saul meminta petunjuk lewat urim dan tumim ia tidak mendapat jawaban pada hari itu. Dalam Kej. 28 : 30 dikemukakan bahwa urim dan tumim dibawa pada bagian dada "efod" atau jubah imam. ${ }^{24}$ Apa yang dilakukan oleh imam tersebut menunjukan bahwa imam tidak langsung menetapkan keputusan yang akan diambilnya tetapi terlebih dahulu ia harus melibatkan Tuhan didalam pengambilan keputusan.

\section{Harus Dapat Membedakan Kudus dan Tidak Kudus, Najis dan Tidak Najis}

Salah satu peran imam yakni harus dapat membedakan antara kudus dan tidak kudus serta najis dan tidak najis. Hal ini berkaitan dengan perannya dalam ibadah yang harus berhadapan dengan Allah yang yang mahakudus sehingga seorang imam harus menjaga kekudusan dirinya. Mereka tidak diperbolehkan meminum anggur dan minuman keras bila masuk ke kemah pertemuan (Im. 10:9). Imam keturunan Harun tidak diperbolehkan bersentuhan dengan mayat atau melakukan upacara perkabungan. Mereka tidak boleh menajiskan diri dengan orang mati, kecuali kalau yang mati itu adalah kerabat terdekatnya, ibu, ayah, anak atau saudaranya (Im. 21:1-5). Alasan mengapa para imam tidak boleh menajiskan diri dengan orang mati dengan menyentuh mereka karena maut adalah hukuman dosa, maka bersentuhan dengan yang mati dianggap menajiskan diri. ${ }^{25}$ Keadaan orang mati pun najis. Ritus perkabungan yang lazim dalam kebudayaan

\footnotetext{
22 Roy B. Zuck, Teologi Alkitabiah Perjanjian Lama (Malang: Gandum Mas, 2015), 112.

${ }^{23}$ Charles F. Pfeiffer dan Everett F. Harrison, The Wycliffe Bible Commentary, Terj. Hananiel Nugroho (Malang: Gandum Mas, 2014), 263. 459.

${ }^{24}$ A. Simanjuntak, Tafsiran Alkitab Masa Kini (Jakarta: Yayasan Komunikasi Bina Kasih/ OMF, 1998), 25 Ibid, 221.
} 
Kanaan dianggap najis (Ul. 14:1-2; Im. 19:27-28; 21:5). ${ }^{26}$ Para imam tidak diperbolehkan memperistri perempuan sundal, perempuan yang tidak perawan lagi atau perempuan yang diceraikan suaminya (Im. 21:6-7). ${ }^{27}$ Allah itu kudus sehingga para imam sangat penting untuk bisa membedakan mana yang kudus dan tidak kudus dan karena imam adalah milik Allah yang kudus dan melayani Allah yang kudus sehingga seluruh kehidupan mereka harus ditandai dengan kekudusan.

Berkaitan dengan peran ini, imam juga sekaligus melakukan pengajaran (torah) terhadap sejumlah pertanyaan yang berkaitan dengan ibadah dan prakteknya. Seorang imam harus mampu memberikan pernyataan apakah suatu benda, tempat atau orang tahir atau tidak tahir, suci atau berdosa dan dengan demikian mereka memberikan bimbingan kepada orang yang sedang beribadah (Im. 10 : 8 - 11; Yeh. 22 : 26). ${ }^{28}$ Hal ini menunjukan bahwa imam memilki tugas sebagai pengantara yang mewakili Allah kepada umat dan juga umat kepada Allah.

a. Mempersembahkan korban dan berdoa.

b. Mereka harus memberi pertimbangan, apakah dapat dianggap bersih seseorang yang tadinya dianggap najis; dalam perkara-perkara kecemburuan mereka meminta putusan Allah. Dalam perkara-perkara sulit mereka memberi nasihat, oleh karena mereka mahir dalam hukum Allah. ${ }^{29}$ Tugas imam tidak hanya pada peribadatan kepada Allah saja tetapi juga menangani persoalan umat dengan umat lainnya.

c. Memberi berkat dalam nama Allah. Hanya imam yang boleh mengucapkan berkat kepada bangsa Israel. Ucapan berkat terdapat dalam Bil. 6 : 22 - 27. Ucapan tersebut merupakan ucapan berkat imam yang indah, dalam gaya puisi Semit yang sempurna dan sarat dengan pesan yang sangat diperlukan oleh orang-orang yang menghadapi berbagai ketidakpastian serta aneka ketakutan yang bermusuhan dari kehidupan dipadang gurun. Ucapan berkat tersebut berbicara tentang kebaikan Allah di dalam memelihara dan melindungi umatNya. ${ }^{30}$ Peran imam dalam memberkati bangsa Israel merupakan sebuah peran yang menunjukan bahwa Imam adalah wakil Allah ditengah-tengah bangsa Israel.

d. Ia adalah bapa dan penasehat umat Allah. Seorang imam bertanggungjawab atas segala acara dan upacara persembahan di kemah suci atau tempat suci. Mereka hidup dari sebagian persembahan yang dipersembahkan oleh umat. ${ }^{31}$

Hal ini berkaitan dengan tugas imam sebagai pelayan yang khusus bekerja di kemah suci. Orang Lewi sebagai pelayan imam pertama-tama disuruh mendekat, barangkali kepada TUHAN dan sesudahnya menghadap Harun, ayat 6b-10 adalah tugas dan hak

${ }^{26}$ Christoph Barth dan Marie-Cliare Barth-Frommel, Teologi Perjanjian Lama 1, 7 ed. (Jakarta: PT BPK Gunung Mulia, 2016), 342.

27 Lembaga Biblika Indonesia, Pengantar ke Dalam Taurat, 138.

${ }^{28}$ Maidiantius Tanyid, "Budaya Keimaman Orang Kristen: Sebuah Kajian Teologis dan Praktis tentang Budaya Keimaman Dalam Praktek Kehidupan Orang Kristen Masa Kini,” Umpuran Mali’ 2, no. 2 (2015), 1.

${ }^{29}$ F.L. Baker, Sejarah Kerajaan Allah 1 (Jakarta: PT BPK Gunung Mulia, 2016), 363.

${ }^{30}$ Charles F. Pfeiffer dan Everett F. Harrison, The Wycliffe Bible Commentary, 339.

${ }^{31}$ S. Wismoady Wahono, Di Sini Kutemukan: Petunjuk Mempelajari dan Mengajarkan Alkitab (Jakarta: PT BPK Gunung Mulia, 2016), 193. 
istimewa seluruh suku Lewi untuk melayani TUHAN. Tapi ada pembagian tugas di dalam suku itu. Harun dan anak-anaknya menyelesaikan tugas imamat dan sisa suku itu melayani mereka untuk menunaikan tugas-tugas di kemah suci bagi para imam dan seluruh umat. ${ }^{32}$ Peran suku Lewi begitu terstruktur dan tertata dengan baik, setelah imam melaksanakan tugasnya maka suku lewi yang bukan keturunan imam segera melaksanakan tugasnya terutama dalam hal memelihara barang-barang kudus dalam kemah suci. 33

Adapun dua fungsi utama dari orang Lewi yakni: ${ }^{34}$

1. Menjaga Kemah Suci

Dalam menjaga kemah suci, mereka harus waspada jangan sampai ada orang awam yang mendekat dan menyentuh barang-barang kudus di kemah suci. Mereka harus siap untuk membunuh orang-orang yang mendekati tenda pertemuan itu. Larangan mendekati kemah suci sudah diberitahukan terlebih dahulu kepada umat.

2. Membongkar dan Memasang Kemah Suci

Orang Lewi memiliki tugas untuk membongkar kemah suci ketika bangsa itu berpindah dan memasang kemah itu ketika bangsa itu menetap pada suatu tempat.

Bangsa Israel merupakan bangsa nomaden sehingga kemah suci harus berpindah dari suatu tempat ketempat yang lain. Bilangan 3 dan 4 berisi sensus yang diperintahkan Tuhan kepada Musa. Bilangan 3 merupakan sensus untuk laki-laki yang berusia lebih dari sebulan untuk memeriksa bahwa jumlah orang Lewi sama dengan jumlah anak sulung di suku-suku lainnya. Anak sulung laki-laki di Israel lebih banyak daripada orang Lewi sehingga anak sulung tersebut harus ditebus dengan cara dibayar. Sensus dalam Bilangan 4 diperuntukkan bagi laki-laki berusia tiga puluh dan lima puluh tahun. Sensus tersebut berguna untuk mendistribusikan pekerjaan pembongkaran, pengangkutan dan pendirian kemah suci. Pekerjaan tersebut merupakan pekerjaan yang berat dan berbahaya.

Setalah sensus dilaksanakan maka terdapat pembagian tugas diantara orang Lewi. Tugas orang Kehat dalam Bilangan 4 yaitu mengurus barang-barang yang maha kudus. Mereka yang harus mengangkat barang-barang di kemah pertemuan. Memperhatikan tugas orang Kehat di kemah suci, mereka bertanggung jawab atas bagian-bagian perlengkapan kemah suci yang paling kudus dengan tempat yang mahakudus. Segala barang tersebut terlalu kudus untuk diangkut dengan kereta, maka harus diusung (Bil. $4: 14,15)$. Orang Kehat tidak boleh melihat dan menjamah barang-barang kudus yang akan mereka usung. Harun dan anak-anaknya yang harus membongkarnya dan membungkus barang-barang kudus dari tempat kudus itu sedemikian rupa. Setelah Harun dan anak-anaknya menudungi semua barang kudus itu, lalu diserahkan kepada orang-

\footnotetext{
${ }^{32}$ A. Simanjuntak, Tafsiran Alkitab Masa Kini, 242.

${ }^{33}$ S. Wismoady Wahono, Di Sini Kutemukan: Petunjuk Mempelajari dan Mengajarkan Alkitab, 193.

34Philip J. Budd, Word Biblical Commentary: Number (Texas: Waco, 1984), 76.
} 
orang Kehat untuk diangkut. ${ }^{35}$ Tugas orang kehat merupakan tugas yang sangat dekat dengan Imam dan berhubungan dengan perobotan yang paling suci.

Tugas orang Gerson dalam Bilangan 4 yakni mengangkat tenda-tenda kemah suci dan kemah pertemuan, tirai pintu kemah pertemuan, layar-layar pelataran dan tirai pintu gerbang pelataran yang ada sekeliling kemah suci dan mezbah, dengan talinya dan segala perkakas untuk pekerjaan jabatan mereka. Kelompok orang Gerson bertanggungjawab terhadap perkakas kemah suci yang kurang begitu kudus. Untuk mengangkutnya disediakan kereta (Bil. 7:7). ${ }^{36}$ Walaupun orang Gerson bertanggung jawab terhadap perkakas yang kurang begitu kudus, namun mereka tetap melaksanakannya tepat seperti yang diperintahkan oleh Tuhan.

Tugas kaum Merari dalam Bilangan 4 adalah mengangkat papan-papan kemah suci, kayu-kayu lintangnya, tiang-tiangnya, alas-alasnya, tiang-tiang pelataran sekelilingnya, alas-alasnya, patok-patok dan tali-talinya, serta segala perkakasnya. Tugas kaum Merari merupakan tugas yang paling rendah dari segala tugas, yaitu pengawasan dan pengangkutan rangka-rangka dan barang-barang tambahan. Untuk mengangkut barang-barang tersebut disediakan juga kereta (Bil. 7:80). ${ }^{37}$ Memperhatikan tugas orang Merari, itu merupakan tugas yang sangat sederhana namun tugas tersebut tetaplah menyangkut peribadatan kepada Tuhan dan tetap menuntut kesetiaan mereka dalam melaksanakan tugas tersebut. Suku Lewi melaksanakan perannya dengan setia dihadapan Tuhan. Kedua anak Imam Harun yakni Nadab dan Abihu mempersembahkan korban yang tidak diinginkan oleh Tuhan. Peristiwa tersebut membuat mereka mendapat hukuman hingga mati dihadapan Tuhan karena tidak melakukan tepat seperti yang diperintahkan oleh Tuhan. Ketika melaksanakan perannya, suku Lewi dituntun untuk tetap setia dan melakukan perannya dengan baik dalam menyelenggarakan ibadat di kemah suci.

Kehidupan suku Lewi dalam hal peribadatan dan pendeta masa kini merupakan dua konteks kehidupan yang berbeda, tetapi baik suku Lewi maupun pendeta masa kini merupakan pemimpin rohani di tengah-tengah umat. Penulis melihat bahwa kehidupan suku Lewi sebagai pelayan di kemah suci perlu direfleksikan kembali oleh pendeta dalam melaksanakan tugasnya. Pelayanan suku Lewi di kemah suci begitu terstruktur dan tertata dengan rapi. Masing-masing pihak mengerjakan tugasnya dan jika memperhatikan tugas tersebut itu merupakan tugas yang sederhana namun tetap dilaksanakan dengan penuh kedisiplinan. Jika melihat tugas tersebut hanya mengangkat peralatan kemah suci, mengurus meja roti tetapi mereka tetap melaksanakan tugas tersebut, tepat seperti yang diperintahkan Tuhan. Pola pelayanan tersebutlah yang perlu dilihat kembali untuk menjadi acuan dalam pelayanan pendeta masa kini di tengah jemaat. Hal yang paling penting ialah bagaimana seorang pendeta

\footnotetext{
${ }^{35}$ A. Simanjuntak, Tafsiran Alkitab Masa Kini, 243.

36Ibid, 245.

${ }^{37}$ A. Simanjuntak, Tafsiran Alkitab Masa Kini (Jakarta: Yayasan Komunikasi Bina Kasih/ OMF, 1998).
} 
harus melibatkan Tuhan didalam setiap pengambilan keputusan, sama seperti suku Lewi yang menggunakan urim dan Tumim untuk mengetahui kehendak Tuhan.

Adapun peran suku Lewi yang bisa direfleksikan kembali oleh pendeta masa kini adalah : Melibatkan Tuhan didalam pengambilan keputusan, menjadi penasehat umat, memberikan pertimbangan tentang persoalan yang dihadapi oleh umat, mengajarkan firman Tuhan, memberkati umat, bertanggungjawab atas perabotan-perabotan di dalam kemah suci, bekerjasama dengan pelayan lain. Tidak hanya menyangkut peran, tetapi aspek kekudusan hidup dari seorang Lewi juga merupakan hal yang sangat penting. Suku Lewi harus memiliki taraf kekudusan melebihi orang-orang sebangsanya. Seorang pendeta harus menjaga kekudusan hidupnya dihadapan Tuhan. Pendeta merupakan sosok penting dan memiliki pengaruh dalam jemaat. Sebagai seorang pendeta maka harus benar-benar siap mengemban tugas sebagai teladan. Sebab keteladan lebih keras berbicara daripada apa yang yang dikatakan, sehingga sepatutnyalah pendeta melakukan apa yang disampaikan lewat khotbah dan memberikan teladan kepada jemaat.

\section{Kesimpulan}

Kehidupan suku Lewi dan kehidupan pendeta masa kini merupakan dua konteks yang berbeda, namun baik suku Lewi maupun pendeta masa kini merupakan pelayan Tuhan. Sebagai seorang pelayan Tuhan, pendeta perlu melihat dan merefleksikan kembali kehidupan suku Lewi. Pelayanan suku Lewi begitu terstruktur dan tertata dengan baik. Masing-masing pihak mengerjakan tugasnya dan jika memperhatikan tugas tersebut, itu merupakan tugas yang sederhana namun tetap dilaksanakan dengan penuh kedisiplinan. Tidak hanya menyangkut peran tetapi kekudusan hidup sangatlah penting dari seorang pelayan Tuhan. Pendeta adalah manusia biasa namun ia harus mengusahakan hidup dalam kekudusan untuk melayani Tuhan yang kudus.

\section{Referensi}

Armstrong, Karen. Sejarah Alkitab; Telaah Historis atas Kitab yang Paling Banyak Dibaca di Seluruh Dunia. Bandung: Mizan, 2014.

Baker, F.L. Sejarah Kerajaan Allah 1. Jakarta: PT BPK Gunung Mulia, 2016.

Barth, Christoph dan Marie-Cliare Barth-Frommel. Teologi Perjanjian Lama 1. 7 ed. Jakarta: PT BPK Gunung Mulia, 2016.

Bloomendal, J. Pengantar Kepada Perjanjian Lama. Jakarta: PT BPK Gunung Mulia, 2008. Budd, Philip J. Word Biblical Commentary: Number. Texas: Waco, 1984.

Hadianto, Jarot. Misteri Ular Tembaga: Mengenal Kitab Taurat dan Merenungkannya. Jakarta: Lembaga Biblika Indonesia, 2017.

Hayes, John H. dan Carl R. Holladay. Pedoman Penafsiran Alkitab. Jakarta: BPK Gunung Mulia, 2013.

LaSor, W.S. dkk. Pengantar Perjanjian Lama 1: Taurat dan Sejarah. Jakarta: PT BPK Gunung Mulia, 2015.

Lembaga Alkitab Indonesia. Tafsiran Alkitab Perjanjian Lama. Yogyakarta: PT Kanisius, 2002.

Lembaga Biblika Indonesia. Pengantar ke Dalam Taurat. Yogyakarta: Kanisius, 2017. 
Mawene, Marthinus Theodorus Perjanjian Lama dan Teologi Kontekstual. Jakarta: PT BPK Gunung Mulia, 2012.

Park, Abraham. Pertemuan yang Terlupakan. Jakarta: Grasindo Yayasan Damai Sejahtera Utama, 2011.

Pfeiffer, Charles F. dan Everett F. Harrison. The Wycliffe Bible Commentary. Terjemahan Hananiel Nugroho. Malang: Gandum Mas, 2014.

Rowley, H.H. Ibadat Israel Kuno. Terjemahan I.J. Cairns. Jakarta: PT BPK Gunung Mulia, 2014.

Simanjuntak. A. Tafsiran Alkitab Masa Kini. Jakarta: Yayasan Komunikasi Bina Kasih/ OMF, 1998.

Snoek, I. Sejarah Suci. Jakarta: PT BPK Gunung Mulia, 2015.

Subagyo, Andreas B. Pengantar Riset Kuantitatif dan Kualitatif: Termasuk Riset Teologi dan Keagamaan. Bandung: Yayasan Kalam Hidup, 2014.

Tanyid, Maidiantius “Budaya Keimaman Orang Kristen: Sebuah Kajian Teologis dan Praktis tentang Budaya Keimaman Dalam Praktek Kehidupan Orang Kristen Masa Kini." Umpuran Mali' 2, no. 2 (2015).

Wahono, S. Wismoady. Di Sini Kutemukan: Petunjuk Mempelajari dan Mengajarkan Alkitab. Jakarta: PT BPK Gunung Mulia, 2016.

Wongsa, Peter Latihan Bagi Umat Allah: Pendidikan Teologi Dalam Kitab Bilangan. Malang: Seminari Alkitab Asia Tenggara, 1988.

Zuck, Roy B. Teologi Alkitabiah Perjanjian Lama. Malang: Gandum Mas, 2015.

A. Simanjuntak. Tafsiran Alkitab Masa Kini. Jakarta: Yayasan Komunikasi Bina Kasih/ OMF, 1998.

Abraham Park. Pertemuan Yang Terlupakan. Jakarta: Grasindo Yayasan Damai Sejahtera Utama, 2011.

Andreas B. Subagyo. Pengantar Riset Kuantitatif Dan Kualitatif: Termasuk Riset Teologi Dan Keagamaan. Bandung: Yayasan Kalam Hidup, 2014.

Charles F. Pfeiffer dan Everett F. Harrison. The Wycliffe Bible Commentary. Edited by Hananiel Nugroho. Malang: Gandum Mas, 2014.

Christoph Barth dan Marie-Cliare Barth-Frommel. Teologi Perjanjian Lama 1. 7th ed. Jakarta: PT BPK Gunung Mulia, 2016.

F.L. Baker. Sejarah Kerajaan Allah 1. Jakarta: PT BPK Gunung Mulia, 2016.

H.H. Rowley. Ibadat Israel Kuno. Edited by I.J. Cairns. Jakarta: PT BPK Gunung Mulia, 2014.

I. Snoek. Sejarah Suci. Jakarta: PT BPK Gunung Mulia, 2015.

J. Bloomendal. Pengantar Kepada Perjanjian Lama. Jakarta: PT BPK Gunung Mulia, 2008. Jarot Hadianto. Misteri Ular Tembaga: Mengenal Kitab Taurat Dan Merenungkannya. Jakarta: Lembaga Biblika Indonesia, 2017.

John H. Hayes dan Carl R. Holladay. Pedoman Penafsiran Alkitab. Jakarta: BPK Gunung Mulia, 2013.

Karen Armstrong. Sejarah Alkitab; Telaah Historis Atas Kitab Yang Paling Banyak Dibaca Di Seluruh Dunia. Bandung: Mizan, 2014.

Lembaga Biblika Indonesia. Pengantar Ke Dalam Taurat. Yogyakarta: Kanisius, 2017.

_—_. Tafsiran Alkitab Perjanjian Lama. Yogyakarta: PT Kanisius, 2002.

Maidiantius Tanyid. "Budaya Keimaman Orang Kristen: Sebuah Kajian Teologis Dan Praktis Tentang Budaya Keimaman Dalam Praktek Kehidupan Orang Kristen Masa Kini." Umpuran Mali' 2, no. 2 (2015). 
Marthinus Theodorus Mawene. Perjanjian Lama Dan Teologi Kontekstual. Jakarta: PT BPK Gunung Mulia, 2012.

Peter Wongsa. Latihan Bagi Umat Allah: Pendidikan Teologi Dalam Kitab Bilangan. Malang: Seminari Alkitab Asia Tenggara, 1988.

Philip J. Budd. Word Biblical Commentary: Number. Texas: Waco, 1984.

- - - World Biblical Commentary: Number. Texas: Waco, 1984.

Roy B. Zuck. Teologi Alkitabiah Perjanjian Lama. Malang: Gandum Mas, 2015.

S. Wismoady Wahono. Di Sini Kutemukan: Petunjuk Mempelajari Dan Mengajarkan Alkitab. Jakarta: PT BPK Gunung Mulia, 2016.

W.S. LaSor, dkk. Pengantar Perjanjian Lama 1: Taurat Dan Sejarah. Jakarta: PT BPK Gunung Mulia, 2015. 